Prospect of solar-driven ejector-compression hybrid refrigeration system with low GWP refrigerants in summer of Guangzhou and Beijing Wang, X., Yan, Y., Li, B., Hao, X., Gao, N., Chen, G..

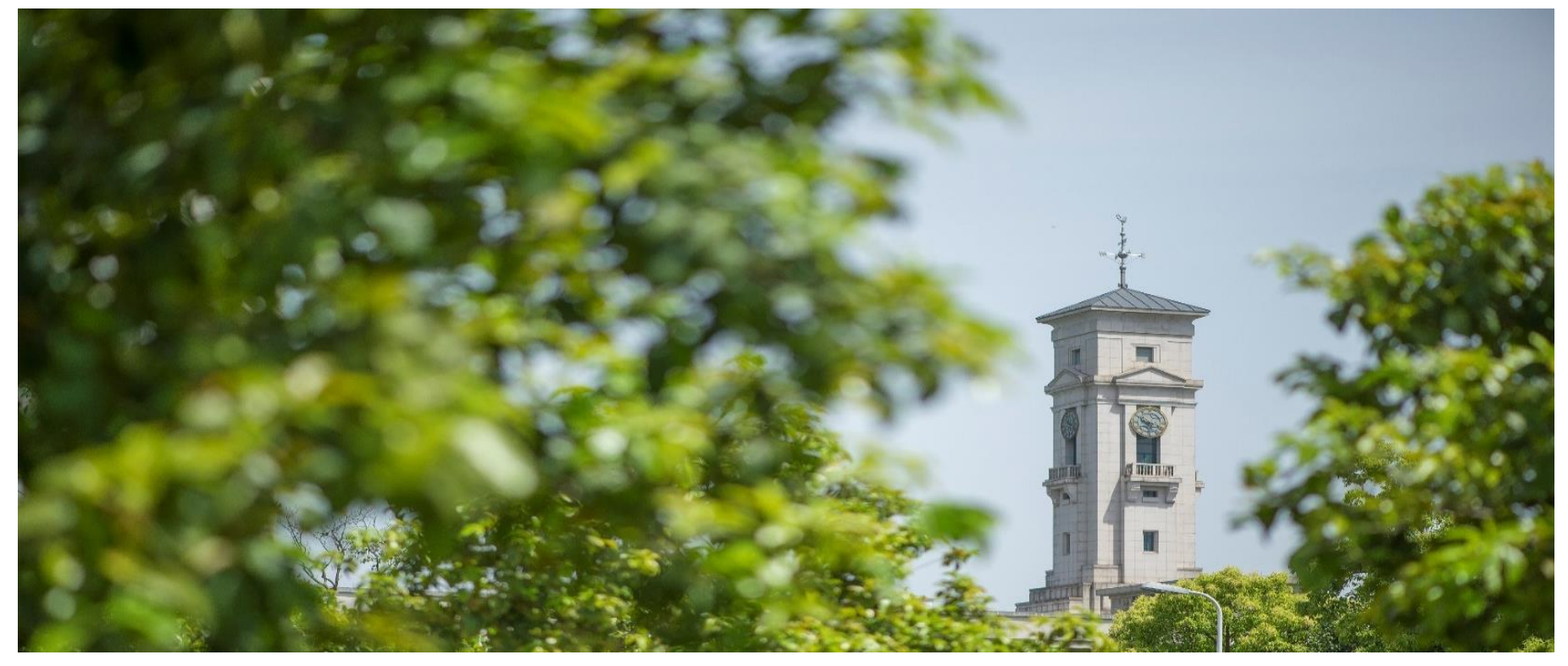


University of Nottingham Ningbo China, 199 Taikang East Road, Ningbo, 315100, China

First published 2020

This work is made available under the terms of the Creative Commons Attribution 4.0 International License:

http://creativecommons.org/licenses/by/4.0

The work is licenced to the University of Nottingham Ningbo China under the Global University Publication Licence:

https://www.nottingham.edu.cn/en/library/documents/researchsupport/global-university-publications-licence.pdf Nottingham 


\title{
Prospect of Solar-driven Ejector-Compression Hybrid Refrigeration System with Low GWP Refrigerants in Summer of Guangzhou and Beijing
}

Xuehui Wang ${ }^{1}$, Yuying Yan ${ }^{1,3 *}$, Bo Li ${ }^{1}$, Xinyue $\mathrm{Hao}^{2}$, Neng $\mathrm{Gao}^{2}$, Guangming Chen ${ }^{2}$

(1. Fluids and Thermal Engineering Research Group, Faculty of Engineering, University of Nottingham, UK,

NG7 2RD)

(2. Ningbo Institute of Technology, Zhejiang University, Ningbo, China 315100)

(3. Research Centre for Fluids and Thermal Engineering, University of Nottingham Ningbo China, Ningbo, China

315100)

\begin{abstract}
:
In this paper, the prospect of low-GWP refrigerants used in solar-driven ejector-compression hybrid refrigeration system was analyzed and evaluated based on the solar radiation data in summer of Beijing and Guangzhou. Prominent environmental friendly alternative refrigerants, including HCFO-1233zd(E), HFO-1336mzz(Z), HFO-1234ze(Z), HCFO-1224yd(Z) and HC-600 were chosen as the working fluids to address the environmental concerns, while HFC-245fa was used as the baseline refrigerant. The hybrid refrigeration system composed of an ejector refrigeration system as the upper stage and a vapor compression system as the bottom stage, respectively. The results indicated that the system with HFO-1234ze(Z) showed the highest COP. HFO-1234ze(Z) was followed by HCFO-1233zd(E) and HC-600, and all of them showed higher COP than that of HFC-245fa. The system with HC-600 needed more electric energy than any other systems, while HFO-1336mzz(Z) consumed the lowest electric power. Meanwhile, the performances of HFO-1234ze(Z) and HFC-245fa systems were further compared. It was found that for both working fluids, the heat load of the condenser $\left(Q_{e, c}\right)$, total electric energy consumption $\left(W_{e}\right)$ and electric energy of compressor $\left(W_{\text {com }}\right)$ in August were the highest in Beijing, while in Guangzhou, the highest of them was achieved in September. It was also suggested that the solar radiation had no influence on the relative magnitude of the $Q_{e, c}, W_{e}$ and $W_{\text {com }}$ between HFO-1234ze(Z) and HFC-245fa systems. The $Q_{e, c}, W_{e}$ and $W_{\text {com }}$ of the system with HFO-1234ze(Z) were higher than those of HFC-245fa by $0.8 \%, 4.44 \%$, and $3.55 \%$, respectively.
\end{abstract}

Key Words: Low GWP refrigerants; solar energy; solar-driven refrigeration system; HFO; ejector;

\begin{tabular}{cccc}
\hline $\begin{array}{c}\text { Nomenclature } \\
\mu\end{array}$ & entrainment ratio & $e$, con,in & condenser inlet, upper stage \\
$w$ & velocity $\left(\mathrm{m} \cdot \mathrm{s}^{-1}\right)$ & $e, c o n, o$ & condenser outlet, upper stage \\
$\eta$ & efficiency & $e, e v, o$ & evaporator outlet, upper stage \\
$n \&$ & mass flow rate $\left(\mathrm{kg} \cdot \mathrm{s}^{-1}\right)$ & $e, e v$, in & evaporator inlet, upper stage \\
$h$ & enthalpy $\left(\mathrm{kJ} \cdot \mathrm{kg}^{-1}\right)$ & $e, g$ & generator, upper stage \\
$H$ & average daytime $(\mathrm{h})$ & $e, p r i m$ & primary fluid, upper stage \\
$E C$ & energy consumption $(\mathrm{kwh})$ & $e$, sec & second fluid, upper stage \\
$Q$ & heat load $(\mathrm{kW})$ & gen,o & generator outlet \\
$N$ & number of day & gen,in & generator inlet \\
$W$ & work $(\mathrm{kW})$ & $m i x$ & mixed fluid \\
$T$ & temperature $\left({ }^{\circ} \mathrm{C}\right)$ & $m i x$, do & mixed fluid, diffuser outlet \\
\hline
\end{tabular}

* Corresponding author: Prof. Yuying Yan. E-mail: yuying.yan@nottingham.ac.uk. Tel: +44 (0) 1159513168 


\begin{tabular}{cccc}
\hline subscripts & compressor & mix,do,s & mixed fluid, diffuser outlet, isentropic process \\
com & condenser outlet, bottom stage & $n$ & nozzle \\
com,con,o & evaporator, bottom stage & $n i, p r i$ & nozzle outlet, primary fluid \\
com, $e v$ & compressor outlet & no,pri,s & nozzle inlet, primary fluid \\
com, $o$ & compressor inlet & pump & pump \\
com, $i n$ & diffuser & pump,in & inlet of pump \\
$d$ & electric & pump,o & outlet of pump \\
$e$ & condenser, upper stage & & \\
$e, c$ & &
\end{tabular}

\section{Introduction}

With the great improvement of modern society, the demanding for energy increases rapidly [1-3]. According to BP Energy Outlook 2019, a 32\% increase of the primary energy consumption will be expected by $2040^{[4]}$. Nevertheless, in this context, the exploration of renewable energy sources has been intensified while the use of fossil fuels is restricted due to the concerns about global warming, climate change, and $\mathrm{CO}_{2}$ emission. Many governments and organizations have issued lots of plans to boost the role of sustainable energy in the economy. As an energy source been used from the very beginning of human history, solar energy has a very low environmental pollution and can be a good choice from the long run ${ }^{[5,6]}$. One of the distinguished methods to use solar energy is photo-thermal conversion and then uses the thermal energy to produce the electricity, work or the cooling/heating effect ${ }^{[7]}$. Many systems and devices were developed to make the best use of solar energy in a certain area. Due to some apparent advantages such as quick construction, simple structure, installation and nearly-zero maintenance ${ }^{[8,9]}$, the ejector system has attracted wide attention of the scholars and has proved to be a reliable method to utilize the solar energy. In an ejector system, the key component is the ejector, which is a device that increases the pressure of the secondary or entrained stream, and obtains the middle-pressure mixed flow. During the operational process, there is no need to use neither mechanical equipment nor devices with moving parts ${ }^{[10,11]}$.

Over the past decades, many brilliant investigations have been reported on the performance of ejector refrigeration systems and most of them were tested with hydrofluorocarbons (HFC) refrigerants, such as HFC-134a, HFC-245fa, HFC-236fa, HFC-141b and HFC-152a. However, due to their high GWPs ${ }^{[12]}$, they will be surely substituted by more environment-friendly refrigerants in the coming future ${ }^{[13]}$. Recently, some new fourth-generation refrigerants are proposed, such as hydrofluoroolefin (HFO)/ hydrochlorofluoroolefin (HCFO) refrigerants. They are the derivatives of unsaturated hydrocarbons and had very short life-spans in the atmosphere. Therefore, their GWPs are very small when compared with existing refrigerants ${ }^{[14-16]}$. Some $\mathrm{HFO} / \mathrm{HCFO}$ refrigerants are very suitable to be used in the ejector refrigeration system and have already drawn the attention of the scholars. Gagan et al ${ }^{[17]}$ experimentally investigated the performance and the efficiency of the ejector system with HFO-1234ze(E). It was suggested that the system operated well even when the temperature of the heat source was as low as $50^{\circ} \mathrm{C}$. The entrainment ratio of the ejector in the nominal design condition could be 0.25 . Smierciew et al. ${ }^{[18]}$ experimentally investigated the performance of the ejector refrigeration system driven by a low-temperature heat source with HFO-1234ze(Z). The experimental results indicated that the ejector refrigeration system with HFO-1234ze(Z) showed a competitive performance and had a good prospect when utilizing a heat source whose temperature was below $70{ }^{\circ} \mathrm{C}$. Fang et al ${ }^{[19]}$ investigated the alternative potential of HFO-1234yf and HFO-1234ze(E) to the HFC-134a. It was found that R1234yf proved to be a good drop-in candidate for HFC-134a ejector refrigeration system, despite the replacement would cause a slight decrease of COP. Regarding the 
HFO-1234ze(E), under the same condition, the entrainment ratio, COP and cooling capacity would decrease by $5.2 \%, 9.6 \%$ and $19.8 \%$ when compared with those of HFC-134a. In 2018, to further Fang et al [19] contribution, Gil et al ${ }^{[20]}$ theoretically analyzed the performance of ejector refrigeration system with HFC-134a and various $\mathrm{HFO} / \mathrm{HCFO}$ refrigerants in different working ranges. It was suggested that while HFO-1243zf and HFO-1234ze(E) systems presented the highest COP, no refrigerants could well cover all the testing range. Meanwhile, HFO-1216 and HFO-1234yf seemed not to be good candidates for the ejector system operating in the testing range.

This paper is aimed to further investigate the prospect of new environmental-friendly refrigerants used in the ejector refrigeration system. The performance of a typical solar-driven ejector-compression hybrid refrigeration system was theoretically analyzed with the refrigerant of HC-600, HFO-1234ze(Z), HCFO-1224yd(Z), HCFO-1233zd(E) and HFO-1336mzz(Z) against summer solar radiation data of Beijing and Guangzhou. HFC-245fa was selected as the baseline refrigerant as it commonly used in the ejector refrigeration system. This paper is expected to be a good reference for the following research.

\section{Solar-driven ejector-compression hybrid refrigeration (SEHR) system}

\subsection{The ejector-compression hybrid refrigeration system}

An SEHR system is analyzed in this work and the schematic diagram of the cycle is presented in Fig.1 (a). The vapor compression refrigeration cycle is used as the bottom stage, and the ejector refrigeration system is used as the upper stage. The two stages combined with each other by an intercooler. The vapor compression refrigeration stage composes of a compressor, an intercooler, an expansive valve, and an evaporator. The ejector refrigeration stage consists of a generator, ejector, condenser, vapor-liquid separator, feed pump of the refrigerant, and intercooler. The vapor-liquid separator is used to make the studied system well in accordance with the practical experimental rigs. In the upper stage, the refrigerant becomes high-pressure and high-temperature vapor after absorbing the heat in the generator. This fluid will entrain the low-pressure refrigerant from the intercooler in the ejector. The mixed refrigerant then is cooled to liquid in the condenser. In the vapor-liquid separator, the refrigerant is divided into two fluids. One fluid decreases the pressure after an expansion valve and flows to the intercooler. Another fluid is directly pumped returning to the generator by a feed pump ${ }^{[21]}$. The generator is heated by solar energy, which is collected by a solar collector as shown in Fig.1 (a). The $p$ - $h$ diagram of the cycle is shown in Fig. 1(b).

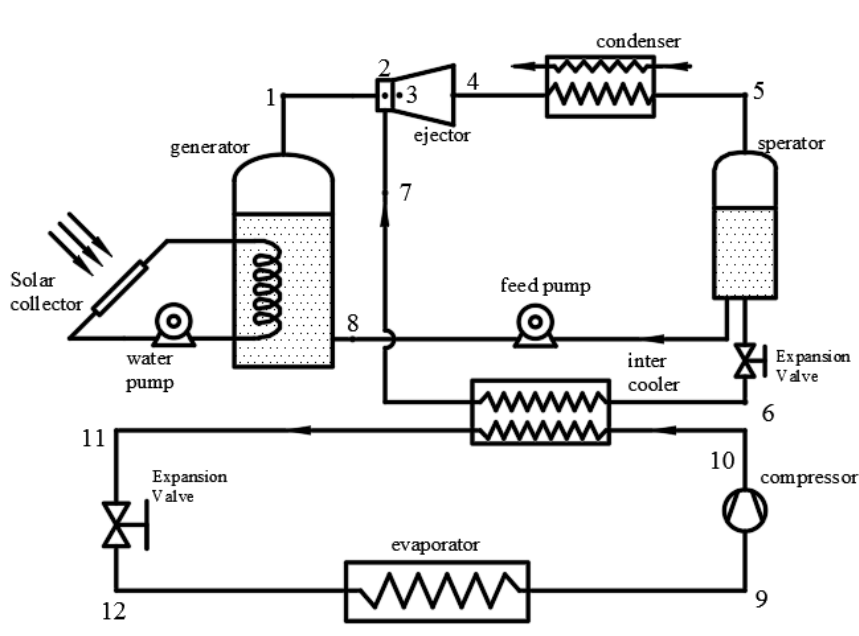

(a)
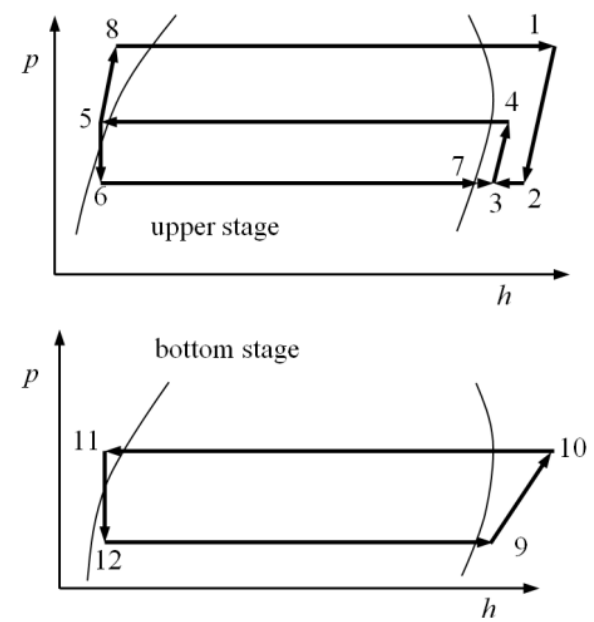

(b)

Fig. 1 Schematic diagram of the hybrid refrigeration cycle (a) system diagram; (b) $p$ - $h$ diagram

\subsection{The refrigerants}


In the effort to search for more environmental friendly refrigerants, some new unsaturated materials are proposed as the alternative refrigerants. Due to the unsaturated characteristics in their molecule structures, the lifespans of them in the atmosphere are very short. As a result, the GWPs of them are very small when compared with HFC refrigerants. Among these potential alternative refrigerants, the saturated vapour lines of some refrigerants form positive slope in their $T$-s diagrams. They are very suitable to be used in the ejector refrigeration systems due to no phase change during the expansion process in the nozzle. The $p-T$ diagram of potential refrigerants is shown in Fig.2. In Fig.2, it can be concluded that the $p$ - $T$ characteristics of HC-600, HFO-1234ze(Z), HFC-245fa, HCFO-1224yd(Z), and HCFO-1233zd(E), and HFO-1336mzz(Z) are similar. From this point of view, they can be potential alternatives to HFC-245fa without too significant modifications of the system. In this paper, the performances of SEHR system with these refrigerants were investigated and analyzed to evaluate the prospect of these refrigerants. HFC-245fa was selected as the baseline refrigerant.

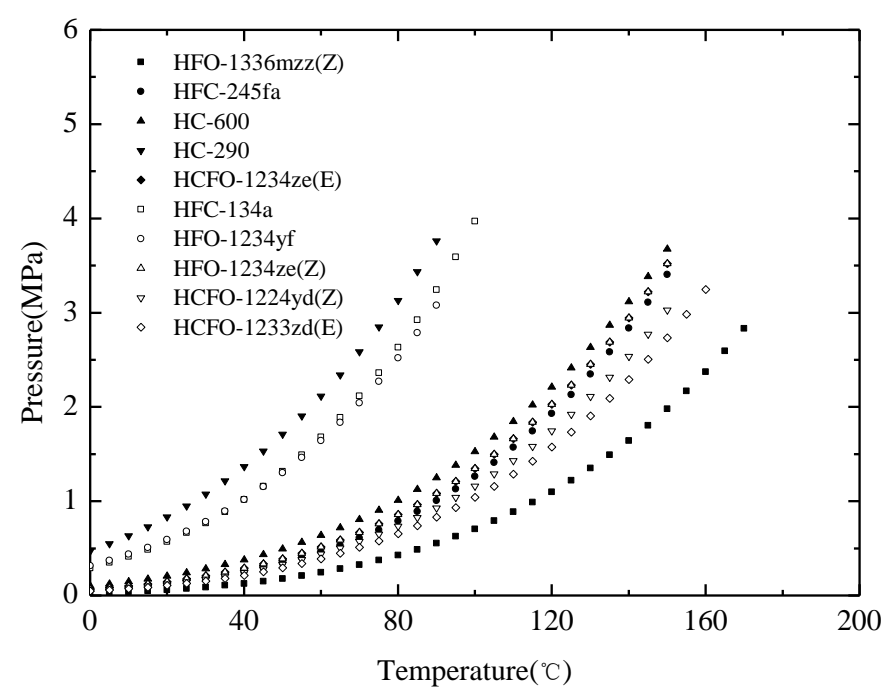

Fig. 2 The $p-T$ diagram of the refrigerants

The detailed thermophysical properties of these refrigerants are listed in Table.1. It should be noted that despite the ODPs of HCFO-1233zd(E) and HCFO-1224yd(Z) are not 0 , but the value is almost zero and it has a very short atmosphere life. Therefore, they are also treated as an environmental-friendly refrigerant.

Table 1 physical property of the refrigerants ${ }^{[22-26]}$

\begin{tabular}{|c|c|c|c|c|c|c|}
\hline Properties & HFC-245fa & HC-600 & HFO-1234ze(Z) & HCFO-1224yd(Z) & HCFO-1233zd(E) & HFO-1336mzz(Z) \\
\hline $\begin{array}{l}\text { Chemical } \\
\text { formula }\end{array}$ & $\mathrm{CF} 3 \mathrm{CH} 2 \mathrm{CHF} 2$ & $\mathrm{CH} 3(\mathrm{CH} 2) 2 \mathrm{CH} 3$ & $\mathrm{CHF}=\mathrm{CHCF} 3$ & $\mathrm{CF} 3 \mathrm{CF}=\mathrm{CHCL}$ & $\mathrm{CF} 3 \mathrm{CH}=\mathrm{CHCl}$ & $\mathrm{CF} 3 \mathrm{CH}=\mathrm{CHCF} 3$ \\
\hline $\begin{array}{c}\text { Critical } \\
\text { temperature(K) }\end{array}$ & 427.16 & 425.13 & 423.27 & 428.69 & 439.6 & 444.5 \\
\hline $\begin{array}{c}\text { Critical } \\
\text { pressure(MPa) }\end{array}$ & 3.65 & 3.796 & 3.531 & 3.337 & 3.624 & 2.903 \\
\hline $\begin{array}{c}\text { Mole } \\
\text { weight }\left(\mathrm{g} \cdot \mathrm{mol}^{-1}\right)\end{array}$ & 134 & 58.122 & 114.04 & 148.49 & 130.5 & 164.06 \\
\hline Slope & positive & positive & positive & positive & positive & positive \\
\hline Safety Group & B1 & A3 & $\mathrm{A} 2 \mathrm{~L}$ & $\mathrm{~A} 1$ & $\mathrm{~A} 1$ & $\mathrm{~A} 1$ \\
\hline ODP & 0 & 0 & 0 & 00012 & 0.00034 & 0 \\
\hline
\end{tabular}




\begin{tabular}{ccccccc}
\hline GWP & 858 & 4 & $<10$ & 0.88 & 7 & 9 \\
$\begin{array}{c}\text { Normal boiling } \\
\text { point (K) }\end{array}$ & 287.96 & 272.66 & 282.88 & 287.77 & 291.41 & 306.6 \\
\begin{tabular}{c} 
lifespan \\
\hline
\end{tabular} & $7.7 \mathrm{y}$ & -- & $10 \mathrm{~d}$ & $20 \mathrm{~d}$ & $25 \mathrm{~d}$ & $26 \mathrm{~d}$ \\
\hline
\end{tabular}

\subsection{The solar radiation data used in this paper}

To evaluate the performance of the system, the solar radiation data were used as the input of the hybrid refrigeration system. The data of Beijing and Guangzhou in July, August and September were collected from EnergyPlus weather Data center ${ }^{[27]}$. The information of key data used in the analysis was listed in Table 2. It was assumed that the area of the solar collector was $100 \mathrm{~m}^{2}$. Meanwhile, the efficiency of the solar collector in the literature was generally within the range of $0.6 \sim 0.8{ }^{[28-30]}$. In this paper, the efficiency of 0.7 was assumed for the solar collector.

Table 2 the key solar radiation data used in the analysis

\begin{tabular}{|c|c|c|c|c|c|c|c|}
\hline \multirow[b]{2}{*}{ Location } & \multirow[b]{2}{*}{ Data source } & \multicolumn{2}{|c|}{ July } & \multicolumn{2}{|c|}{ Aug } & \multicolumn{2}{|c|}{ Sep } \\
\hline & & $\begin{array}{c}\text { Hours } \\
\text { average }\end{array}$ & $\begin{array}{c}\text { Daily } \\
\text { average }\end{array}$ & $\begin{array}{c}\text { Hours } \\
\text { average }\end{array}$ & $\begin{array}{c}\text { Daily } \\
\text { average }\end{array}$ & $\begin{array}{c}\text { Hours } \\
\text { average }\end{array}$ & $\begin{array}{c}\text { Daily } \\
\text { average }\end{array}$ \\
\hline \multirow{4}{*}{ Beijing } & CSWD, WMO & & & & & & \\
\hline & Station No & 327.6 & 4753.35 & 340.2 & 4617.9 & 302.5 & 3732.75 \\
\hline & 545110 & $\mathrm{~W} \cdot \mathrm{m}^{-2}$ & $\mathrm{~W} \cdot \mathrm{m}^{-2}$ & $\mathrm{~W} \cdot \mathrm{m}^{-2}$ & $\mathrm{~W} \cdot \mathrm{m}^{-2}$ & $\mathrm{~W} \cdot \mathrm{m}^{-2}$ & $\mathrm{~W} \cdot \mathrm{m}^{-2}$ \\
\hline & Elevation $31 \mathrm{~m}$ & & & & & & \\
\hline \multirow{4}{*}{ Guangzhou } & CSWD, WMO & & & & & & \\
\hline & Station No & 286.65 & 3827.25 & 302.4 & 3861.9 & 311.85 & 3802.05 \\
\hline & 592870 & $\mathrm{~W} \cdot \mathrm{m}^{-2}$ & $\mathrm{~W} \cdot \mathrm{m}^{-2}$ & $\mathrm{~W} \cdot \mathrm{m}^{-2}$ & $\mathrm{~W} \cdot \mathrm{m}^{-2}$ & $\mathrm{~W} \cdot \mathrm{m}^{-2}$ & $\mathrm{~W} \cdot \mathrm{m}^{-2}$ \\
\hline & Elevation $41 \mathrm{~m}$ & & & & & & \\
\hline
\end{tabular}

\section{The thermodynamic modeling of the system}

Some basic assumptions are made to analyze the system and are shown as follows,

1) All the components in the system have no heat leak to the environment, the heat transfer process only happens between the refrigerant and coolant.

2) For both stages, the throttling in the expansion valve is isenthalpic.

3) The flow of the refrigerant in the ejector is irreversible, and the irreversibility is described by the isentropic coefficient

4) For all the exchangers, the sub-cool and superheat of the refrigerant are $5 \mathrm{~K}$

\subsection{Calculation of the entrainment ratio of the ejector}

The ejector is a key component in the upper stage, its performance can be evaluated by the entrainment ratio, and it is defined by ${ }^{[31,32]}$

$$
\mu=n k_{e, \text { sec }} / n_{e, p r i m}^{k_{e}}
$$

In this paper, the entrainment ratio is calculated by the models proposed by Yan et al ${ }^{[33]}$. In this model, the irreversibility of the flow process in the ejector is defined by coefficients correlated from the experimental data. When the ejector works, the inlet velocity of the primary flow is very small compared with the flow inside of the ejector. If the inlet velocity is neglected, the velocity of the primary fluid at the nozzle outlet will be 


$$
w_{n o}=\sqrt{2000 \eta_{n}\left(h_{n i, p r i}-h_{n o, p r i, s}\right)}
$$

Meanwhile, if the inlet velocity of the second fluid is also neglected, in the mixing chamber, according to the conservation of the momentum and the energy, the average velocity and the enthalpy of the mixed fluid can be obtained and given by

$$
\begin{aligned}
& w_{\text {mix }}=\sqrt{\eta_{\text {mix }}} w_{\text {no,pri }} /(1+\mu) \\
& h_{\text {mix }}=\frac{\left(h_{n o, p r i}+\mu h_{e, s e c}\right)}{1+\mu}-\frac{w_{m i x}{ }^{2}}{2000}
\end{aligned}
$$

In this way, the enthalpy of the mixed fluid at the outlet of the ejector can also be given by,

$$
h_{\text {mix }, d o}=h_{\text {mix }}+\left(h_{m i x, d o, s}-h_{\text {mix }}\right) / \eta_{d}
$$

From the energy conservation point, the enthalpy of the mixed fluid can also be obtained by,

$$
h_{\text {mix }, d o}=h_{m i x}+w_{\text {mix }}^{2} / 2000
$$

The irreversibility of the nozzle, mixing chamber and diffuser used in this paper are $\eta_{n}=0.85, \eta_{\text {mix }}=0.95$, $\eta_{\mathrm{d}}=0.85^{[34,35]}$. By combining all the equations above, the entrainment ratio of the ejector can be calculated. The thermodynamic properties of the refrigerants in different conditions are obtained from the software REFPROP version $10.0^{[36]}$.

The model was first proposed to predict the entrainment ratio of the ejector with HFC refrigerants. It has not been validated for the HFO refrigerants as the author concerns. Fortunately, there are already some experimental data of ejector system with HFO-1234ze(E) had been published by Smierciew et al [37]. In this paper, the model was validated with the experimental data of ejector in double-chock working condition. The validation results are shown in Table. 3. As it can be seen, apart from the last case, the relative deviation between the experimental data and predicted results were within $\pm 9 \%$, which indicated quite a good agreement.

Table 3 the validation of the model with experimental data

\begin{tabular}{cccccc}
\hline$T_{e, p r i m}\left({ }^{\circ} \mathrm{C}\right)$ & $T_{e, s e c}\left({ }^{\circ} \mathrm{C}\right)$ & $T_{e, c}\left({ }^{\circ} \mathrm{C}\right)$ & $\mu_{\text {exp }}$ & $\mu_{\text {pre }}$ & Relative deviation \\
\hline 72.1 & -6.7 & 18.3 & 0.318 & 0.296 & $-6.92 \%$ \\
72.1 & -6.7 & 18.9 & 0.31 & 0.283 & $-8.71 \%$ \\
73.4 & 5.7 & 22.3 & 0.46 & 0.481 & $4.56 \%$ \\
73.4 & 5.7 & 22.6 & 0.46 & 0.469 & $1.95 \%$ \\
72.2 & 2.3 & 23 & 0.31 & 0.324 & $4.52 \%$ \\
72.2 & 2.3 & 24 & 0.3 & 0.324 & $8 \%$ \\
70.3 & 12.5 & 23.2 & 0.362 & 0.311 & $-14.1 \%$ \\
\hline
\end{tabular}

\subsection{Thermodynamic analysis of system}

To compare the performance of the system with different working fluids, other key parameters are also calculated apart from the entrainment ratio according to the thermodynamic analysis. The heat loads of the heat exchangers and electric energy consumption are considered here as they close relatedly with the cost of the system. In the upper stage, the heat loads of the generator, condenser and intercooler are calculated by,

$$
\begin{aligned}
& Q_{e, g}=n \&_{e, p r i}\left(h_{g e n, o}-h_{g e n, i n}\right) \\
& Q_{e, c}=n \alpha_{\text {mix }}\left(h_{e, \text { con,in }}-h_{e, \text { con }, o}\right)
\end{aligned}
$$




$$
Q_{\mathrm{inter}}{ }^{\prime}=h_{\mathrm{e}, \mathrm{sec}}^{\mathrm{\alpha}}\left(h_{e, e v, o}-h_{e, e v, i n}\right)
$$

In the bottom stage, the heat loads of the evaporator and intercooler are given by,

$$
\begin{aligned}
& Q_{\text {inter }}=n \&_{c o m}\left(h_{\text {com }, o}-h_{\text {com }, \text { con }, o}\right) \\
& Q_{\text {com }, e v}=n \&_{c o m}\left(h_{\text {com }, \text { in }}-h_{\text {com }, \text { con }, o}\right)
\end{aligned}
$$

The electric energy consumed in the system includes two parts,

$$
W_{e}=W_{\text {com }}+W_{\text {pump }}
$$

in which the $W_{\text {com }}$ and $W_{\text {pump }}$ are calculated by ${ }^{[38]}$

$$
\begin{aligned}
& W_{\text {com }}=n \&_{\text {com }}\left(h_{\text {com }, o}-h_{\text {com }, \text { in }}\right) / \eta_{\text {com }} \\
& W_{\text {pump }}=n \&_{e, p r i m}\left(h_{\text {pump }, o}-h_{\text {pump }, \text { in }}\right)
\end{aligned}
$$

in which $\eta_{c o m}$ represents the isentropic efficiency of compressor, and $\eta_{c o m}=0.85^{[39]}$. Furthermore, the coefficient of performance (COP) of the system is given by

$$
\mathrm{COP}=Q_{\text {com }, e v} /\left(W_{e}+Q_{e, g}\right)
$$

In order to solve the equations mentioned-above, a flowchart is developed for the procedures. With all the input parameters, the entrainment ratio of the ejector in the upper stage is obtained firstly by iterating. After that, the electric energy consumption, heat loads of different heat exchangers and COP can be calculated accordingly.

\section{Results and discussions}

\subsection{The performance of the system with different working fluids}

Based on the methodology abovementioned, the performances of the SEHR system with different working fluids are evaluated. It is well-known that efficiency and energy consumption are important aspects of the system. Therefore, the COP, the heat load of the condenser $\left(Q_{e, c}\right)$, and the electric energy consumption $\left(W_{e}\right)$ were selected as criteria to show the effects of the working fluids. Meanwhile, for a SEHR system with a certain working fluid, the COP, the heat load of the condenser and electric energy consumption per unit mass do not change with the input solar radiation. Therefore, any condition of solar radiation can be used to evaluate the working fluids. In this section, the solar radiations of July in Beijing were chosen to show the influence of the working fluids.

Fig. 3 shows the changing of COP, $Q_{e, c}$ and $W_{e}$ with different generator temperature in July of Beijing. As it could be seen from Fig. 3, the system with HFO-1234ze(Z) presented the highest COP, while those of HFO-1336mzz(Z) was the lowest when the generator temperature were within $(85 \sim 97)^{\circ} \mathrm{C}$. HFO-1234ze(Z) was followed by HCFO-1233zd(E) and HC-600, and all of them showed higher COP than that of HFC-245fa. When the generator temperature was $97^{\circ} \mathrm{C}$, the COP of HFO-1234ze $(\mathrm{Z})$ was higher than HFO-1336mzz(Z) by $5.9 \%$, showing the great difference between the working fluids. As the temperatures of evaporator inlet and outlet were the same for these working fluids, the higher COP of HFO-1234ze(Z) system is caused by higher latent heat, which results higher heat capacity of evaporator. The comparison between the condenser heat loads of the system presented a similar trend to COP because the input solar energy was the same. When it came to the electric energy consumption, the system with HC-600 needed more electric energy than any 
other systems. It was higher than those of HFC-245fa, HFO-1234ze(Z), HCFO-1224yd(Z), HFO-1336mzz(Z) and HCFO-1233zd(E) by $6.81 \%, 2.26 \%, 6.81 \%, 16.1 \%$ and $6.35 \%$, respectively. Only the $W_{e}$ of HFO-1336mzz(Z) system was lower than that of HFC-245fa. Regarding the $p$ - $T$ diagrams of all refrigerants studied in this paper, HC-600a and HFO-1336mzz (Z) have maximum and minimum slope, respectively as indicated in Fig.1. Therefore, the pump work, as well as the electric energy needed of system with them is the largest and smallest.
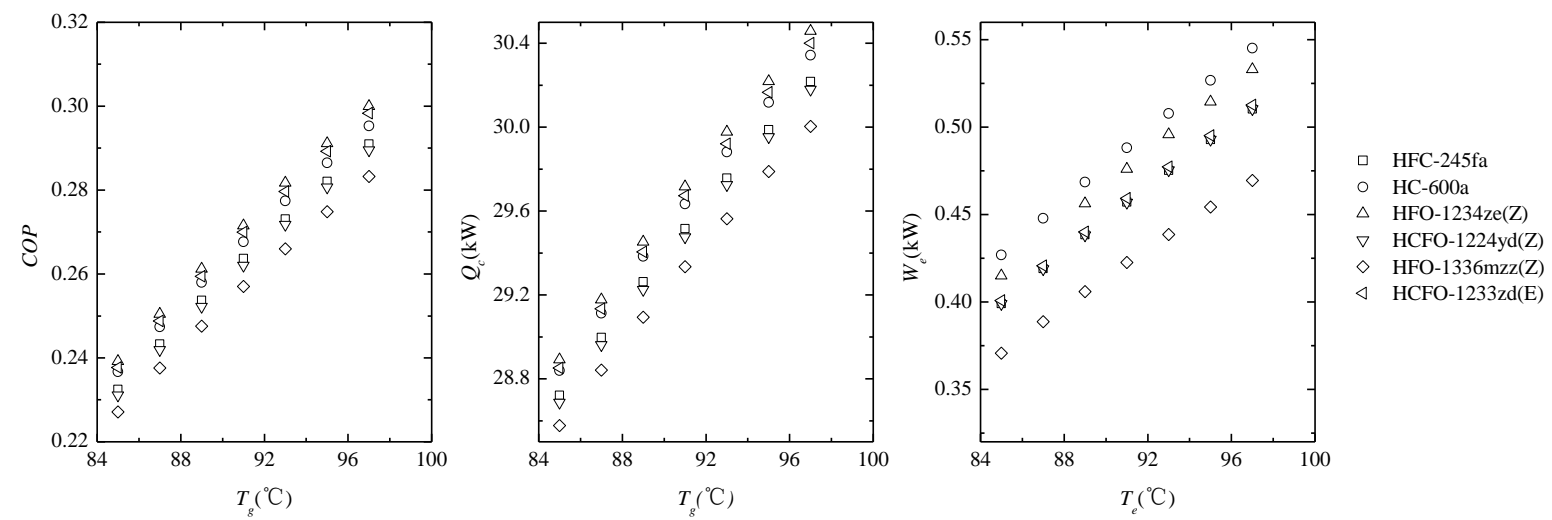

Fig. 3 The influence of generator temperature in July of Beijing (a) on COP; (b) on $Q_{c}$; (c) on $W_{e}$

(Calculation conditions: $T_{e, c}=45^{\circ} \mathrm{C}, T_{c o m, e v}=5^{\circ} \mathrm{C}, T_{c, c o n}=20^{\circ} \mathrm{C}, T_{e, e v}=25^{\circ} \mathrm{C}$ )

Meanwhile, the performance of the system is also influenced by other parameters. One of the important parameters is the evaporator temperature. In the methodology presented in section 2 , the temperature of each fluid and their temperature difference of two fluids in the intercooler were set as constant, so the variation of the evaporator temperature won't influence the upper stage performance (say, $Q_{e, c}$ ). From this point of view, the COP of the system, the electric energy consumption of the compressor $\left(W_{c o m}\right)$ and the total electric energy consumption $\left(W_{\mathrm{e}}\right)$ were used as the criteria here.

Fig. 4 presents the influence of the working fluid on the system performance at different evaporator temperature in July of Beijing. It can be concluded that with the increase of the evaporator temperature, the $\mathrm{COP}$ of the system with all the fluids increased. The COP of HFO-1234ze(Z) was the highest among all the work fluids. Furthermore, the system of HC-600 was expected to consume more electric energy. The conclusions were similar to the influence of the generator temperature, but the influence of the evaporator temperature was slightly less significant than the generator temperature.
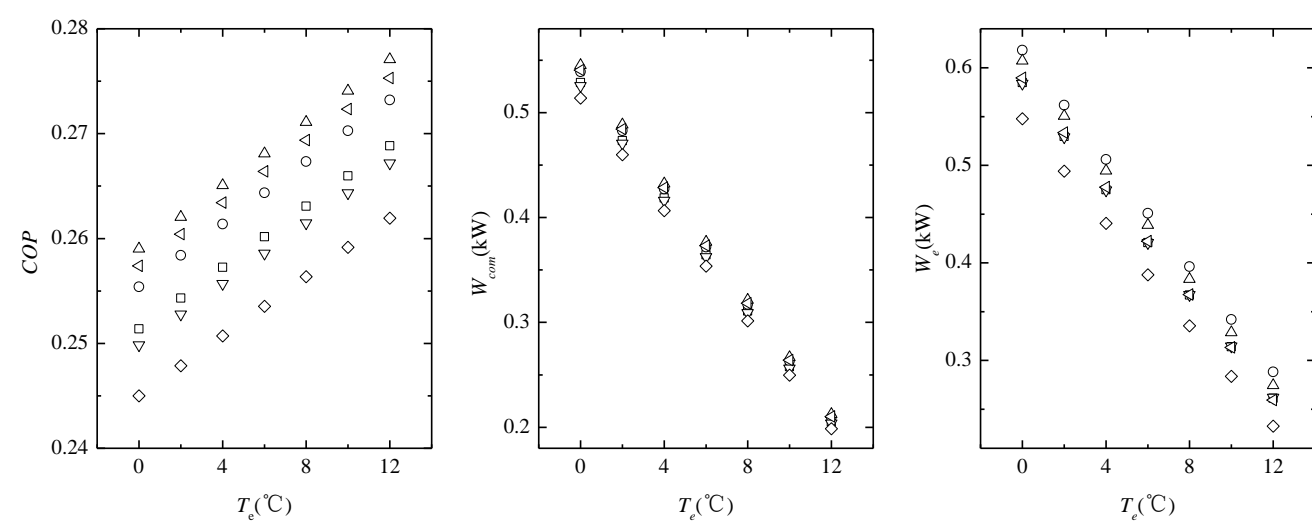

$\square \quad$ HFC-245fa

- HC-600

$\triangle$ HFO-1234ze(Z)

$\nabla$ HCFO-1224yd(Z)

$\diamond$ HFO-1336mzz(Z)

$\triangleleft$ HFO-1233zd(E)

Fig. 4 The influence of evaporator temperature in July of Beijing (a) on COP; (b) on $W_{\text {com }}$; (c) on $W_{e}$ (Calculation conditions: $T_{e, c}=45^{\circ} \mathrm{C}, T_{e, g}=90^{\circ} \mathrm{C}, T_{c, c o n}=20^{\circ} \mathrm{C}, T_{e, e v}=25^{\circ} \mathrm{C}$ ) 


\subsection{The comparison between HFC-245fa and HFO-1234ze(Z) in July, August and September}

From section 4.1, it was found that the performance of the system varied with the working fluids. The COP of the HFO-1234ze(Z) was the highest within the investigation range. It could be a good alternative to HFC-245fa from this point of view. In order to further evaluate the prospect of HFO-1234ze(Z), the performances of the system with HFC-245fa and HFO-1234ze(Z) were studied and compared against the solar radiation conditions of July, August and September in Beijing.

Fig. 5 shows the $Q_{e, c}, W_{e}$ and $W_{\text {com }}$ of the system with HFO-1234ze(Z) and HFC-245fa in Beijing. For both the working fluids, the $Q_{e, c}, W_{e}$ and $W_{c o m}$ of the systems in August were the highest because of the highest solar radiation in that month as it could be seen from table.2. From this point of view, $Q_{e, c}, W_{e}$ and $W_{\text {com }}$ were higher in September than those of August and July as for the Guangzhou case. Nevertheless, the condition of solar radiation had no influence on the relative magnitude of the $Q_{e, c}, W_{e}$ and $W_{c o m}$ between HFO-1234ze(Z) and HFC-245fa systems. The $Q_{e, c}, W_{e}$ and $W_{c o m}$ of the system with HFO-1234ze(Z) were higher than those of HFC-245fa by $0.8 \%, 4.44 \%$, and $3.55 \%$, respectively.
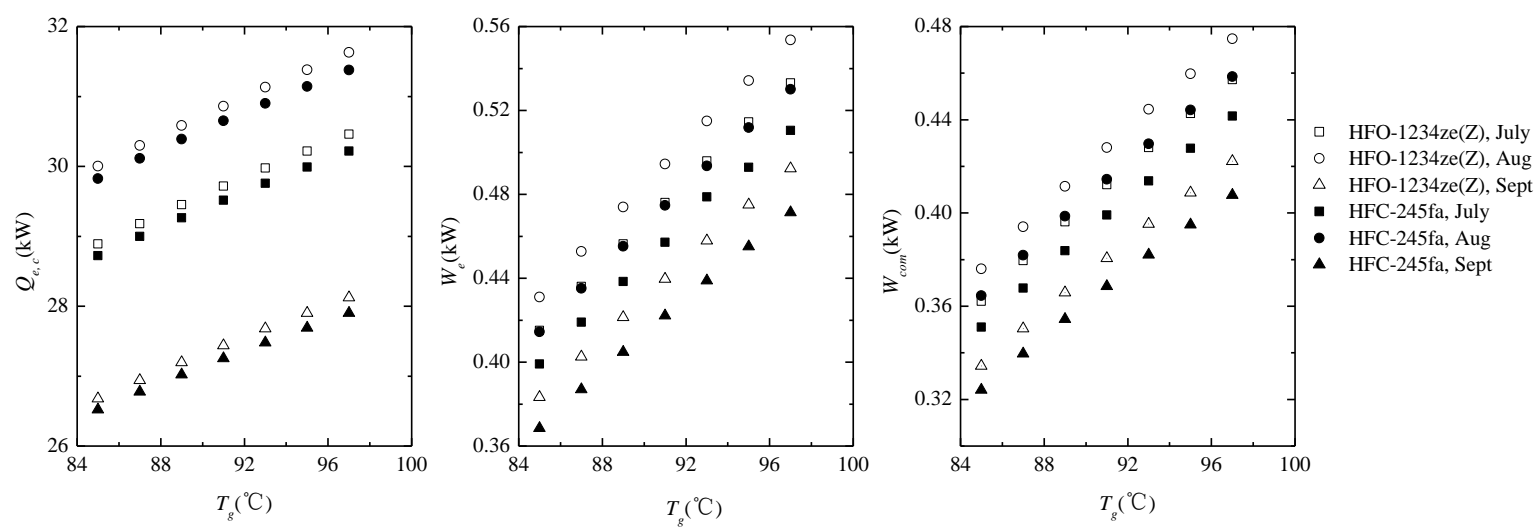

Fig. 5 The comparison between HFC-245fa and HFO-1234ze(Z) in July, August and September of Beijing (a) $Q_{e, c}$; (b) $W_{e}$; (c) $W_{c o m}\left(\right.$ Calculation conditions: $\left.T_{e, c}=45^{\circ} \mathrm{C}, T_{c o m, e v}=5^{\circ} \mathrm{C}, T_{c, c o n}=20^{\circ} \mathrm{C}, T_{e, e v}=25^{\circ} \mathrm{C}\right)$

\subsection{The comparison between HFC-245fa and HFO-1234ze(Z) in Beijing and Guangzhou}

For Beijing and Guangzhou, the length of day time and solar radiation are not identical. In Beijing, the average day time of July, August and September are $14.51 \mathrm{~h}, 13.57 \mathrm{~h}$ and $12.34 \mathrm{~h}$, while those in Guangzhou are $13.35 \mathrm{~h}, 12.77 \mathrm{~h}$ and $12.19 \mathrm{~h}$, respectively. The day time and solar radiation can cause a great effect on the performance of the system. Therefore, the systems with HFO-1234ze(Z) and HFC-245fa were compared based on the solar radiation data of Beijing and Guangzhou in this section. The electric energy consumption was used as the criteria for comparison. It was given by

$$
E C=N W_{e} H
$$



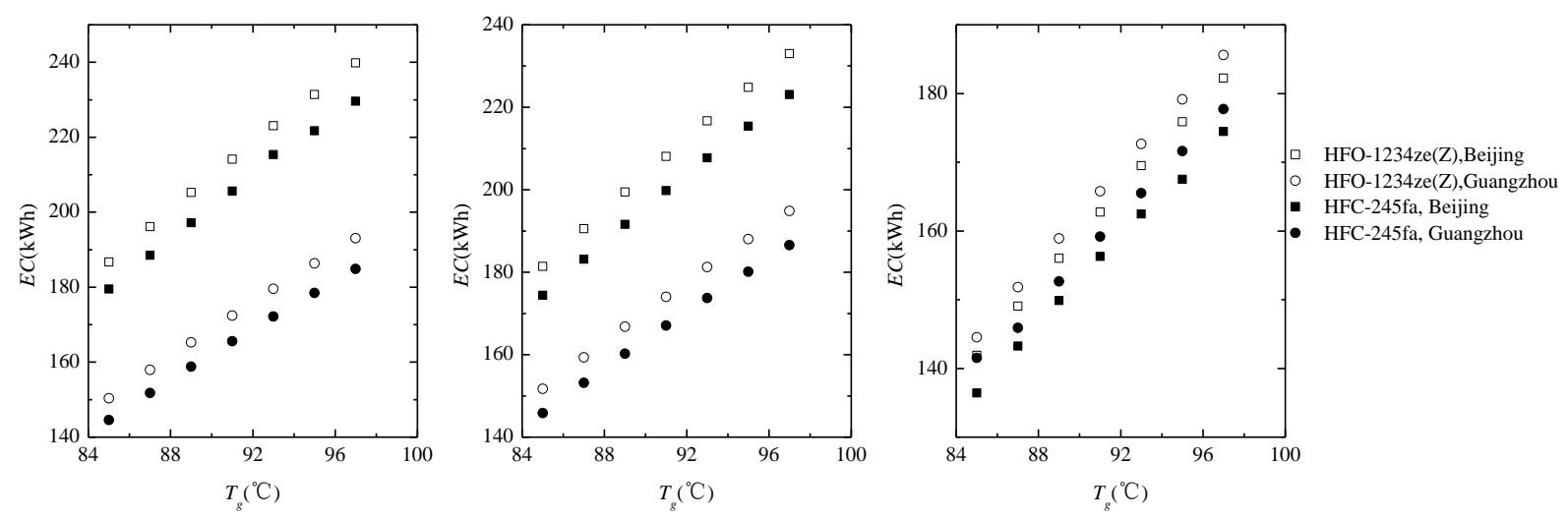

Fig.6 Influence of the location on the $E C$

(a) July; (b) August; (c) September

Fig. 6 shows the $W_{e}$ of HFO-1234ze(Z) and HFC-245fa in July, August, and September of Beijing and Guangzhou, respectively. In July and August, the solar radiations of Beijing are stronger than Guangzhou, therefore, the $W_{e}$ of both HFO-1234ze(Z) and HFC-245fa systems in Beijing were greater. However, in September, it was slightly lower than Guangzhou because of the lower solar radiation.

\section{Conclusions}

In order to evaluate the prospect of the solar-driven ejector refrigeration system with prominent environmental-friendly working fluids including HCFO-1233zd(E), HFO-1336mzz(Z), HFO-1234ze(Z), HCFO-1224yd(Z) and HC-600, the performance of the system was calculated based on the solar radiation data in July, August and September of Beijing and Guangzhou. The system performance of HFC-245fa was used as the baseline. It was found that HFO-1234ze (Z) presented the highest COP, and it was followed by HCFO-1233zd(E) and HC-600. These three refrigerants showed higher COP than that of HFC-245fa. Regarding the electric energy consumption, the system with HC-600 needed more electric energy than any other refrigerants. Meanwhile, the system performances of the HFO-1234ze (Z) and HFC-245fa were further compared. It was found that for both working fluids, the $Q_{e, c}, W_{e}$ and $W_{c o m}$ of the systems in August were the highest in Beijing, while in Guangzhou the highest of them were obtained in September. The $Q_{e, c}, W_{e}$ and $W_{\text {com }}$ of the system with HFO-1234ze(Z) were higher than those of HFC-245fa by $0.8 \%, 4.44 \%$, and $3.55 \%$, respectively.

Despite the paper suggested HFO-1234ze(Z) could be a good choice of alternative refrigerants, more analysis especially the experimental investigations still needed to be done to validate the conclusions here.

\section{Declarations of interest}

None

\section{Acknowledgement}

This work was financially sponsored by the following research grants: H2020-MSCA-RISE - $778104-$ ThermaSMART, Innovate UK (ACeDrive No. 113167), and Ningbo Science and Technology Bureau Technology Innovation Team (No. 2016B10010) 


\section{References}

[1] Zhao GY, Liu ZY, He Y et al. Energy consumption in machining: Classification, prediction, and reduction strategy [J]. Energy, 2017,133:142-157.

[2] Pablo-Romero M, Pozo-Barajas R, Yñiguez R. Global changes in residential energy consumption [J]. Energy Policy, 2017,101:342-352.

[3] Nejat P, Jomehzadeh F, Taheri MM et al. A global review of energy consumption, CO2 emissions and policy in the residential sector (with an overview of the top ten $\mathrm{CO} 2$ emitting countries) [J]. Renewable and Sustainable Energy Reviews, 2015,43:843-862.

[4] BP. BP's Energy Outlook [R].2019.

[5] Kabir E, Kumar P, Kumar S et al. Solar energy: Potential and future prospects [J]. Renewable and Sustainable Energy Reviews, 2018,82:894-900.

[6] Mekhilef S, Saidur R, Safari A. A review on solar energy use in industries [J]. Renewable and Sustainable Energy Reviews, 2011,15(4):1777-1790.

[7] Lewis NS. Research opportunities to advance solar energy utilization [J]. Science, 2016,351(6271):d1920.

[8] Wang XH, Yan Y, Wright E. et al. Prospect evaluation of low-GWP refrigerants R1233zd(E) and R1336mzz(Z) used in solar-driven ejector-vapor compression hybrid refrigeration system [J]. Journal of Thermal Science, 2020. https://doi.org/10.1007/s11630-020-1297-z

[9] Huang BJ, Chang JM, Wang CP et al. A 1-D analysis of ejector performance [J]. International Journal of Refrigeration, 1999,22:354-364.

[10] Yan J, Chen G, Liu C et al. Experimental investigations on a R134a ejector applied in a refrigeration system [J]. Applied Thermal Engineering, 2017,110:1061-1065.

[11] Chen G, Zhang R, Zhu D et al. Experimental study on two-stage ejector refrigeration system driven by two heat sources [J]. International Journal of Refrigeration, 2017,74:295-303.

[12] IPCC. GWP[R].2013.

[13] Wang X, Gao Z, Gao X et al. Investigation on the Vapor - Liquid Equilibrium for the Ternary Mixture HFC-32 + HFC-125 + HFC-161 at Temperatures from 265.15 K to $303.15 \mathrm{~K}$ [J]. Journal of Chemical \& Engineering Data, 2015,60(9):2721-2727.

[14] Tanaka K, Ishikawa J, Kontomaris KK. Thermodynamic properties of HFO-1336mzz(E) ( trans -1,1,1,4,4,4-hexafluoro-2-butene) at saturation conditions [J]. International Journal of Refrigeration, 2017,82:283-287.

[15] Gagan J, Śmierciew K, Butrymowicz D. Performance of ejection refrigeration system operating with R-1234ze(E) driven by ultra-low grade heat source [J]. International Journal of Refrigeration, 2018,88:458-471.

[16] Gao N, Wang XH, Xuan YM et al. An artificial neural network for the residual isobaric heat capacity of liquid HFC and HFO refrigerants [J]. International Journal of Refrigeration, 2019,98: 381-387.

[17] Gagan J, Śmierciew K, Butrymowicz D. Performance of ejection refrigeration system operating with R-1234ze(E) driven by ultra-low grade heat source [J]. International Journal of Refrigeration, 2018,88:458-471.

[18] Śmierciew K, Gagan J, Butrymowicz D et al. Experimental investigation of the first prototype ejector refrigeration system with HFO-1234ze(E) [J]. Applied Thermal Engineering, 2017,110:115-125.

[19] Fang Y, Croquer S, Poncet S et al. Drop-in replacement in a R134 ejector refrigeration cycle by HFO refrigerants [J]. International Journal of Refrigeration, 2017,77:87-98.

[20] Gil B, Kasperski J. Efficiency Evaluation of the Ejector Cooling Cycle using a New Generation of HFO/HCFO Refrigerant as a R134a Replacement [J]. Energies, 2018,11(8):2136. 
[21] Yan J, Cai W, Lin C et al. Experimental study on performance of a hybrid ejector-vapor compression cycle [J]. Energy Conversion and Management, 2016,113:36-43.

[22] Akasaka R, Higashi Y, Miyara A et al. A fundamental equation of state for cis-1,3,3,3-tetrafluoropropene (R-1234ze(Z)) [J]. International Journal of Refrigeration, 2014,44:168-176.

[23] Eyerer S, Dawo F, Kaindl J et al. Experimental investigation of modern ORC working fluids R1224yd(Z) and R1233zd(E) as replacements for R245fa [J]. Applied Energy, 2019,240:946-963.

[24] Yang J, Ye Z, Yu B et al. Simultaneous experimental comparison of low-GWP refrigerants as drop-in replacements to R245fa for Organic Rankine cycle application: R1234ze(Z), R1233zd(E), and R1336mzz(E) [J]. Energy, 2019,173:721-731.

[25] Mateu-Royo C, Navarro-Esbrí J, Mota-Babiloni A et al. Thermodynamic analysis of low GWP alternatives to HFC-245fa in high-temperature heat pumps: HCFO-1224yd(Z), HCFO-1233zd(E) and HFO-1336mzz(Z) [J]. Applied Thermal Engineering, 2019,152:762-777.

[26] Fukuda S, Kondou C, Takata N et al. Low GWP refrigerants R1234ze(E) and R1234ze(Z) for high temperature heat pumps [J]. International Journal of Refrigeration, 2014,40:161-173.

[27] EnergPlus[EB/OL]. https://energyplus.net/weather.

[28] Mahian O, Kianifar A, Kalogirou S A et al. A review of the applications of nanofluids in solar energy [J]. International Journal of Heat and Mass Transfer, 2013,57(2):582-594.

[29] Bhowmik H, Amin R. Efficiency improvement of flat plate solar collector using reflector [J]. Energy Reports, 2017,3:119-123.

[30] Mahbubul IM, Khan M A, Ibrahim NI et al. Carbon nanotube nanofluid in enhancing the efficiency of evacuated tube solar collector [J]. Renewable Energy, 2018,121:36-44.

[31] Xu Y, Jiang N, Wang Q et al. Refrigerant evaluation and performance comparison for a novel hybrid solar-assisted ejection-compression refrigeration cycle [J]. Solar Energy, 2018,160:344-352.

[32] Hamzaoui M, Nesreddine H, Aidoun $\mathrm{Z}$ et al. Experimental study of a low grade heat driven ejector cooling system using the working fluid R245fa [J]. International Journal of Refrigeration, 2018,86:388-400.

[33] Yan G, Chen J, Yu J. Energy and exergy analysis of a new ejector enhanced auto-cascade refrigeration cycle [J]. Energy Conversion and Management, 2015,105:509-517.

[34] Xing M, Yan G, Yu J. Performance evaluation of an ejector subcooled vapor-compression refrigeration cycle [J]. Energy Conversion and Management, 2015,92:431-436.

[35] Yu J, Ren Y, Chen H et al. Applying mechanical subcooling to ejector refrigeration cycle for improving the coefficient of performance [J]. Energy Conversion and Management, 2007,48(4):1193-1199.

[36] Lemmon EW, Bell IH, Huber ML et al. REFPROP[CP/OL].

[37] Śmierciew K, Gagan J, Butrymowicz D et al. Experimental investigation of the first prototype ejector refrigeration system with HFO-1234ze(E) [J]. Applied Thermal Engineering, 2017,110:115-125.

[38] Megdouli K, Tashtoush BM, Nahdi E et al. Performance analysis of a combined vapor compression cycle and ejector cycle for refrigeration cogeneration [J]. International Journal of Refrigeration, 2017,74:517-527.

[39] Zhu ZL, Chen YP, Wu JF, Zhang SB, Zheng SX. A modified Allam cycle without compressors realizing efficient power generation with peak load shifting and CO2 capture [J]. Energy, 2019,174(1):478-487. 